\title{
Partial Genome Organization, Identification of the Coat Protein Gene, and Detection of Grapevine leafroll-associated virus-5
}

\author{
Xin Good and Judit Monis
}

Agritope Inc., 16160 Upper Boones Ferry Road, Portland, OR 97224.

Accepted for publication 22 November 2000.

ABSTRACT

\begin{abstract}
Good, X., and Monis, J. 2001. Partial genome organization, identification of the coat protein gene, and detection of Grapevine leafroll-associated virus-5. Phytopathology 91:274-281.

The genome of Grapevine leafroll-associated virus-5 (GLRaV-5) was cloned, and the sequence of $4766 \mathrm{nt}$ was determined. Degenerate oligonucleotide primers designed from the conserved closterovirus heat shock 70 protein (HSP 70) homologue were used to obtain viral-specific sequences to anchor the cloning of the viral RNA with a genomic walking approach. The partial nucleotide (nt) sequence of GLRaV-5 showed the presence of four open reading frames (ORF A through D), potentially
\end{abstract}

coding for the HSP 70 homologue (ORF A); a 51-kDa protein of unknown function with similarity to GLRaV-3 p55 (ORF B); the viral capsid protein (ORF C); and a diverged viral duplicate capsid protein (ORF D). The ORF C was identified as GLRaV-5 viral capsid protein based on sequence analyses and the reactivity of the recombinant protein to GLRaV-5 specific antibodies by western blot analyses. The antiserum produced with the in vitro-expressed GLRaV-5 ORF C protein product specifically reacted with a 36-kDa polypeptide from GLRaV-5 infected vines but did not react with protein extracts from vines infected with other GLRaVs or uninfected vines. Furthermore, specific primers were designed for the sensitive detection of GLRaV-1 and GLRaV-5 by polymerase chain reaction.
Grapevine leafroll-associated viruses (GLRaVs) are a group of viruses that collectively or individually cause leafroll disease in grape. To date, at least eight different viruses are associated with the grapevine leafroll disease $(24,25)$. The disease is of economical importance and limits the production of grapes throughout the world (12). Based on virion morphology, GLRaVs are placed in the genus Closterovirus group. Closteroviruses are a large and diverse group of filamentous plant viruses with single-stranded RNA genomes, characteristic genome structure, and generally transmitted by insects (16). The group is classified in the family Closteroviridae, comprising two genera, a monopartite genus Closterovirus with type member Beet yellows virus (BYV), and a bipartite genus Crinivirus with type member Lettuce infectious yellows virus $(9,16,20)$. The viruses associated with grapevine leafroll disease (except GLRaV-2) have coat proteins that appear to be larger in molecular weight than those of the genus Closterovirus. The molecular mass of the characterized GLRaVs coat proteins range between 24 and $43 \mathrm{kDa}(5,7,24,27)$, whereas members of the genus Closterovirus, BYV, Citrus tristeza virus (CTV), and GLRaV-2 have coat proteins with lower molecular mass ranging between 22 and $24 \mathrm{kDa}(2,17,19)$.

The partial nucleotide (nt) and deduced amino acid (aa) sequences of the GLRaV-1 (11), the complete GLRaV-2 $(1,36)$ and GLRaV-3 (21) genome nt sequences, and partial GLRaV-4 and GLRaV-5 heat shock 70 protein (HSP) homologue coding sequences (32) have been reported.

A comparison of published nt sequences from GLRaV-3 (21) and GLRaV-2 $(1,36)$ indicates that GLRaV-2 is similar to previously characterized closteroviruses (BYV). In contrast, GLRaV-3 is distinct in both genome organization and sequence relatedness.

Corresponding author: J. Monis; E-mail address: JMonis@ @sveeds.nl

The nucleotide sequences reported in this paper have been deposited in GenBank as Accession Nos. AF233934, AF233935, and AF233936.

Publication no. P-2001-0105-01R

(C) 2001 The American Phytopathological Society
Furthermore, the sequence and molecular data available on genome organization indicates that the order of the capsid protein and diverged duplicate capsid protein is in the reverse order in GLRaV-1 and GLRaV-3, relative to members of the genus Closterovirus $(9,16)$.

The viruses associated with leafroll disease are unevenly distributed in grapevine tissues, exist in low concentration, and are frequently found in mixed infections (26). The purification of individual viruses has been difficult, resulting in antisera that cross-react with the different viruses and host proteins, hampering the reliable detection of these viruses in infected plant material (27). We have used molecular methods to overcome the inherent difficulties of serological detection of these viruses.

In this paper we report the partial nt sequence of GLRaV-5 genomic RNA. The GLRaV-5 capsid protein was identified and subcloned in a bacterial vector for the overexpression of recombinant protein for the production of a high titer antiserum. Furthermore, polymerase chain reaction (PCR) primers were designed for the sensitive detection of GLRaV-1 and GLRaV-5 RNA in infected grapevines.

\section{MATERIALS AND METHODS}

Virus source, RNA isolation, and cDNA synthesis. The LR 100 virus source (13) was used throughout this work. Western blot analyses with monoclonal antibodies (MAbs) (25) and polyclonal antibodies (PAbs) specific to GLRaV-5 suggests that LR 100 is a single-virus infection source. The LR 102 virus source was reported to be infected with GLRaV-1, $-2,-5$, and -8 (25). Other virus sources were described previously (27). Double-stranded (ds) RNA was isolated from mature stem and leaf petioles of infected grapevine material following the procedure described by De Paulo and Powell (8). For cDNA synthesis and cloning, viral RNA was isolated, essentially as described in the kit protocol (RNeasy; Qiagen, Santa Clarita, CA) modified by MacKenzie et al. (23).

Briefly, stem and petiole tissues from infected grapevines were pulverized, and the virus was concentrated by differential cen- 
trifugation as described by Monis and Bestwick (27). The concentrated virus preparation $(300 \mu \mathrm{l})(27)$ was disrupted in Qiagen lysis buffer and processed as described by MacKenzie et al. (23). The RNA was precipitated by the addition of 0.1 vol of $3 \mathrm{M}$ sodium acetate ( $\mathrm{pH}$ 5.2) and $2.5 \mathrm{vol}$ of ethanol, pelleted by centrifugation $(14,000 \times g$ for $10 \mathrm{~min})$, drained, and resuspended in a small volume of nuclease-free water. cDNA libraries were generated by RNA isolated from the LR 100 GLRaV-5 virus source for GLRaV-5-specific libraries as previously described (28).

Genome walking of GLRaV-5 genomic RNA with rapid amplification of cDNA ends by PCR. PCR with degenerate oligonucleotide primers designed from a closterovirus consensus sequence was used to obtain specific GLRaV-5 HSP 70 homologue sequences $(18,35)$. The PCR-derived GLRaV-5 HSP 70 homologue sequences (approximately $600 \mathrm{bp}$ ) were used to design primers for downstream sequence extension. GLRaV-5 cDNA libraries were made with a cDNA amplification kit (Marathon; Clontech Laboratories Inc., Palo Alto, CA) following the manufacturer's protocol. Briefly, after first- and second-strand cDNA synthesis, the adaptors were ligated to the blunt ends of the double-stranded cDNA. This library allowed the rapid amplification of $5^{\prime}$ and $3^{\prime}$ cDNA ends (RACE) by PCR. (Table 1, GLRaV-5 specific primers; Fig. 1, schematic description of cloning strategy).

In the first round of amplification, PCR products were amplified from the GLRaV-5 library with GSP8 and the adaptor prim- ers. The PCR products obtained by cDNA RACE were cloned into a plasmid vector, and colonies were screened. Briefly, bacterial colonies were picked from plates with a toothpick and dipped into a sterile tube containing $15 \mu \mathrm{l}$ of water. After boiling for $3 \mathrm{~min}$, a $3-\mu l$ sample of the mixture was used in PCR reactions with primers M13 1224 and 1233 (New England Biolabs, Beverly, MA). The largest PCR amplification product that reacted to a GLRaV-5 specific probe by Southern blot analyses was chosen and sequenced. Primers were designed based on the sequence of the selected PCR amplification products for subsequent downstream walks. cDNA RACE was repeated sequentially with sequencespecific primers GSP12, GSP15, and GSP23, together with an adaptor primer.

Sequencing and computer-assisted nt and aa sequence analyses. Nucleotide sequencing was performed on both strands of cDNA with a cycle sequencing kit (ABI Taq Dye Deoxy Terminator; Perkin-Elmer Applied Biosystems, Foster City, CA) and a genetic analyzer (ABI 310; Perkin-Elmer). The nt sequences were assembled and analyzed with MacVector DNA analyses programs. The nt and aa sequences of other closteroviruses were obtained with the Entrez program; sequence comparisons with nonredundant databases were searched for with the Blast program from the National Center for Biotechnology Information (NCBI; Bethesda, MD) (3). Pairwise alignments of the deduced HSP 70 homologue, coat protein aa, and diverged duplicate coat protein aa

TABLE 1. Primers for cloning of Grapevine leafroll-associated virus-5 sequences

\begin{tabular}{llcc}
\hline Primer ID & \multicolumn{1}{c}{ Primer sequence } & Genome location & Open reading frame \\
\hline GSP8 & 5' GGCCGTGTCAATTACTGGTAGTGCTGTG 3' & $363-390$ & 1 \\
GSP12 & 5' GCCAGAGAGACCCTTGGACGAGGAATAC 3' & $1407-1434$ & 1 \\
GSP15 & 5' GCAGGTGGATTTCTCTGGTGTGGATGA 3' & $2809-2835$ & 2 \\
GSP23 & 5' GCTGGCGTTTATGCGACTGTTATG 3' & $4206-4229$ & 4 \\
LR5 CP start & 5' ATGTCTGGAGCGTCGCAGAAC 3' & $3285-3305$ & 3 \\
LR5-3F & 5' ACCCGAAGTTGCTGTCTGACC 3' & $3007-3027$ & $2-3$ \\
LR5-2R & 5' CTCGGGCGGCATAACAGTC 3' & $4220-4237$ & 4 \\
\hline
\end{tabular}

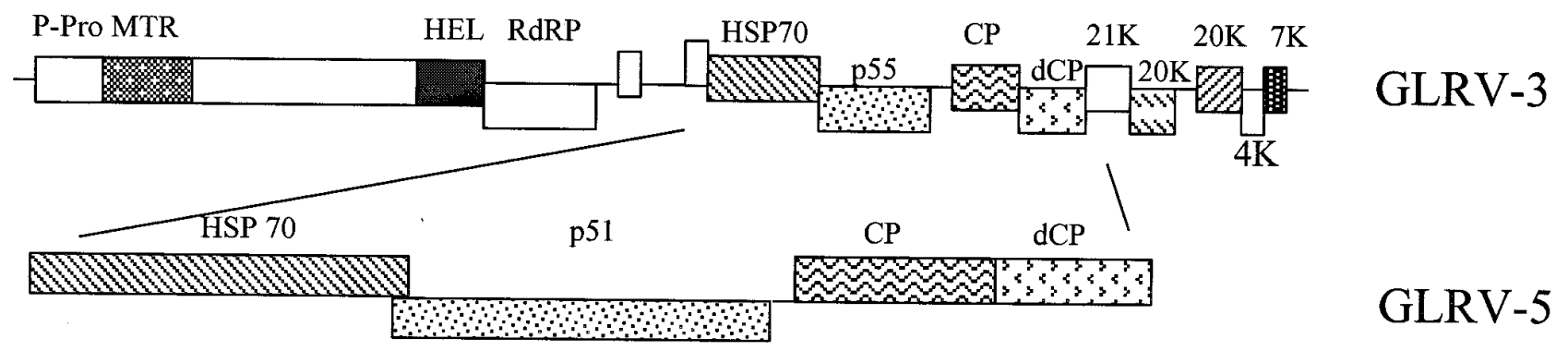

LR100-2

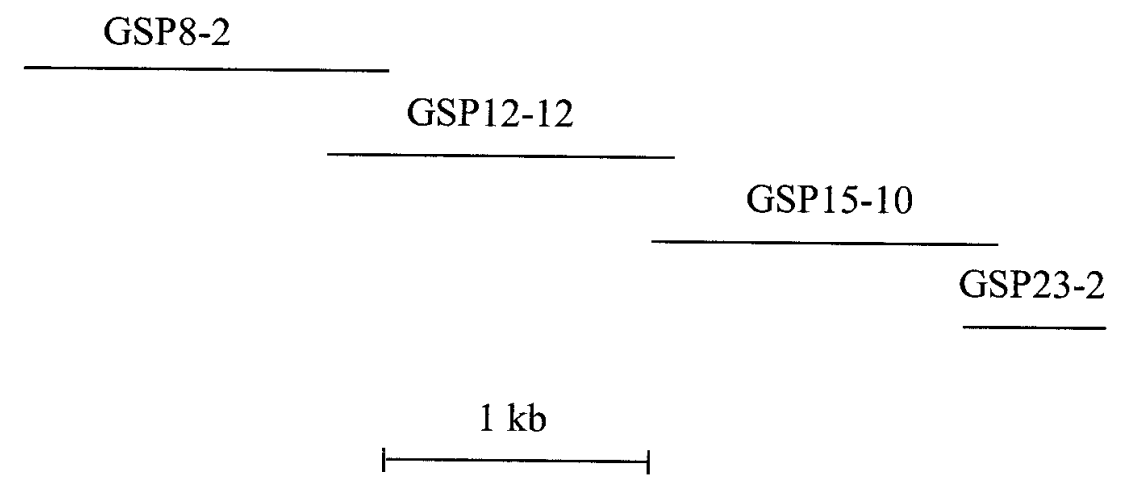

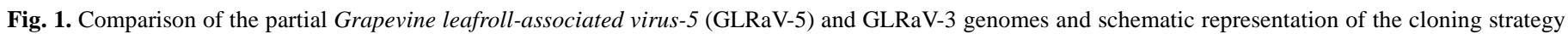

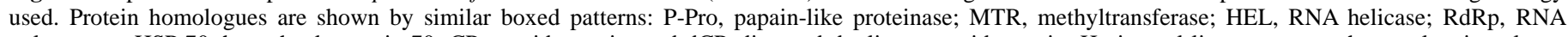

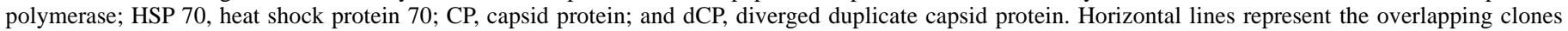
used to determine the nucleotide sequence. 
sequences from other GLRaVs, as well as, selected closterovirus homologous genes were carried out by the DNAStar MegAlign program, CLUSTAL (Baylor Medical School) and the BLAST 2 sequences program (34). The DNAStar MegAlign and the PILE UP multi-alignment program from the PHYLIP package were used in phylogenetic studies comparing the GLRaV-5 HSP 70, coat protein, and diverged duplicate coat protein aa sequences with their closterovirus homologues.

Expression of GLRaV-5 coat protein in vitro and antiserum production. The sequence corresponding to the putative GLRaV5 capsid protein was cloned into a bacterial expression pMALc vector as a maltose binding fusion protein (New England Biolabs). The specific primers LR5 CP start and LR5-2R were used for PCR amplification (Table 1). The PCR products were treated with Vent DNA polymerase (New England Biolabs) and partially digested with HindIII to preserve one blunt end. This strategy allowed the directional cloning of the capsid protein gene into the plasmid's StuI/HindIII sites. The bacterial cell culture (1 liter) was induced with $0.3 \mathrm{mM}$ isopropyl-thio-galactopyranoside, and the recombinant protein (MBP-CP) was purified by an amylose column as described by the manufacturer. After protease factor Xa digestion, protein samples were tested in western blots with specific antibodies. The affinity-purified GLRaV-5 coat protein was used to immunize rabbits for the production of PAbs as previously described (27). The PAb, which will be referred to as rec GLRaV$5 \mathrm{CP}$ PAb, was used in immunoblots for the specific detection of the GLRaV-5 coat protein.

Western blot analysis. Samples of purified fusion protein were analyzed by western blot by GLRaV-5 PAb (Sanofi Diagnostics Pasteur, Marnes-La-Coquette, France), GLRaV-5 MAb (14), and the $15 \mathrm{~F} 1$ broad-spectrum (reactive to GLRaV-5 and -8 ) MAb (25) as described by Monis and Bestwick (27). Different plant material uninfected or infected with GLRaV-5 was used in immunoblots to determine the specificity of the rec GLRaV-5 PAb.

Reverse transcriptase PCR detection of GLRaV-1 and -5. Four sets of PCR primers, for the single or combined detection of GLRaV-1 and -5 , were designed with the nt sequence obtained in this study (Table 2). RNA extracted from concentrated virus preparations or fresh grapevine petioles was used for cDNA synthesis and subsequent PCR. The PCR was carried out as described by MacKenzie et al. (23), except each primer set was annealed at different temperatures: LR5-1F/LR5-1R $\left(62^{\circ} \mathrm{C}\right)$; LR5-5F/LR5-5R $\left(58^{\circ} \mathrm{C}\right)$; GSP1/GSP9 $\left(66^{\circ} \mathrm{C}\right)$; and GSP3/GSP4 $\left(66^{\circ} \mathrm{C}\right)$.

\section{RESULTS}

Genome walking of GLRaV-5 genomic RNA with RACE PCR. The PCR-derived GLRaV-5 HSP 70 homologue sequences (approximately $600 \mathrm{bp}$ ) were used to design primers (Table 1) for downstream cDNA synthesis and cloning. Four overlapping PCR amplification products of 1,115, 1,580, 1,520, and $600 \mathrm{bp}$, and the initial 600-bp PCR product were assembled as a contiguous sequence, for a total of 4,766 bp (Fig. 1).

Analyses and identification of GLRaV-5 coding sequences. Sequence analyses of the $4766 \mathrm{nt}$ of the GLRaV-5 genome

TABLE 2. Primers for the detection of the Grapevine leafroll-associated virus-5 (GLRaV-5) and GLRaV-1 sequences

\begin{tabular}{ll}
\hline Primer ID & \multicolumn{1}{c}{ Primer sequence } \\
\hline LR5-1F & 5' CCCGTGATACAAGGTAGGACA 3' \\
LR5-1R & 5' CAGACTTCACCTCCTGTTAC 3' \\
LR5-5F & 5' TTTGGTGAGAATGGGAGTATG 3' \\
LR5-5R & 5' CTTTCGTCGGCTGACATAGAG 3' \\
GSP3 & 5' CGTTCGCGTTACCCACGCTGCCTA 3' \\
GSP4 & 5' GCTGGCAAACCTGGTGGACTTTACATC 3' \\
GSP1 & 5' CGAAGATGGCCGTGTCAATTACTG 3' \\
GSP9 & 5' CGCCGCCGAAGTCGTAGACAACCA 3' \\
\hline
\end{tabular}

revealed four open reading frames (ORF) designated as ORF A to ORF D (Fig. 1).

ORF A includes the coding sequence for a 530 aa polypeptide with a calculated molecular mass of $58 \mathrm{kDa}$ that has sequence homology to the cellular HSP 70 homologue. The HSP 70 homologue is unique to the plus-sense RNA closterovirus group, and the N-terminal ATPase domain of HSP 70 is highly conserved. The closterovirus HSP 70 has been proposed to play a role in protein-protein interactions such as viral assembly and cell-to-cell movement $(9,29)$.

Alignment of GLRaV-5 HSP 70 coding region with those of other GLRaVs revealed eight conserved motifs present in cellular HSP 70. The use of degenerate primers to clone the partial HSP 70 homologue gene yielded clones with an incomplete $5^{\prime}$ terminus (Fig. 2).

A basic BLASTP search of the nonredundant database through the NCBI (3) with the GLRaV-5 HSP 70 homologue aa sequence indicated the highest similarity with the partial aa sequence of GLRaV-4 HSP 70 homologue (32). The GLRaV-5 HSP 70 shares 29 to $35 \%$ identity with the HSP 70 homologues from the Australian and U.S. strains of GLRaV-1 (11; GenBank Accession No. AF233935); Italian and U.S. strains of GLRaV-2 $(1,36)$; GLRaV-3 (21); and Beet yellow stunt virus (BYSV) (19). Little cherry virus (LChV) (15) showed the lowest sequence similarity with the GLRaV-5 HSP 70 homologue. The percentage of similarity of closterovirus HSP 70 homologues is shown in Table 3.

The phylogenetic analyses showed that GLRaV-5 HSP 70 clustered in the same lineage branch together with the U.S. and Australian strains of GLRaV-1 and GLRaV-3 HSP 70 homologues (data not shown). On the other hand, GLRaV-2 clustered together with members of the genus Closterovirus such as CTV and BYSV, whereas LChV branched in a separate lineage. Unexpected results were obtained when the partial aa sequences of GLRaV-4 and GLRaV-5 (32) were included in the phylogenetic analyses using the PHYLIP package. These partial HSP 70 sequences branched in the same lineage as members of the genus Closterovirus and LChV. In other words, the partial aa sequences of GLRaV-4 and GLRaV-5 appeared to be more related to GLRaV-2, BYSV, and LChV than to the complete GLRaV-5 HSP 70 sequence. This discrepancy was found even when partial aa sequences (most conserved 220 to 240 aa from the $\mathrm{N}$ terminus) of the protein from each viral HSP 70 were used in the analyses (data not shown).

ORF B includes the coding sequence for a 475-aa polypeptide with a calculated molecular mass of $51 \mathrm{kDa}$. A pairwise comparison of GLRaV-5 ORF B with the nonredundant sequence databases through NCBI revealed the highest sequence similarity with GLRaV-3 ORF 5. The polypeptide encoded by the corresponding ORF (p64) from BYV was recently required for viral cell-to-cell movement (4).

ORF C includes the coding sequence for a 269-aa polypeptide with a calculated molecular mass of $29 \mathrm{kDa}$. This ORF was identified as the viral capsid protein based on the presence of a 5-aa signature sequence, SNRGD, found in other closteroviruses (9). To confirm this identification directly, ORF $\mathrm{C}$ was expressed as an MBP-CP fusion protein and was specifically immunoreactive to anti-GLRaV-5 capsid protein antibodies.

Pairwise comparisons of GLRaV-5 coat protein aa sequence indicated similarity with the GLRaV-3, GLRaV-1, and BYSV capsid protein genes (Fig. 3; Table 3)

ORF D includes the coding sequence for a 207 aa polypeptide with a calculated molecular mass of $23 \mathrm{kDa}$. Sequence analysis suggests that ORF D encodes a partial sequence of the GLRaV-5 diverged duplicate capsid protein based on the presence of 4 out of 5 aa (SNGD) of the signature sequence found in closterovirus capsid and diverged duplicate capsid proteins. A search of nonredundant nucleic acid sequence databases with the GLRaV-5 ORF $D$ revealed sequence identity with a GLRaV-4 gene of unknown function (10). No sequence similarity between ORF C and D was 


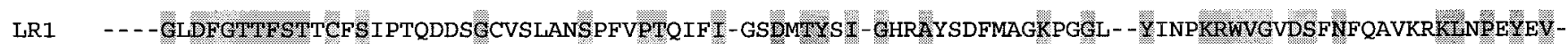
USLR2 MVVFGLDFGTTESTVCVYKDGR WFSFKQ-NNSAYIPTYLYYLF-SESNHMT FGYEAESLMSNLKVKGSF - KRELKRWVGCDSSNLDAY̌ LDRLKPHYSVR

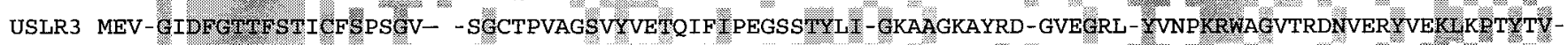

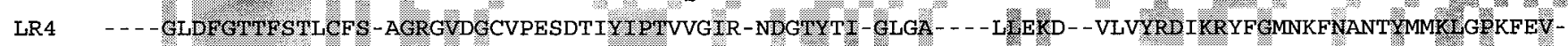
LR5 - - - -GLEFGTTFSTLEFS-AGRGVDGCVPESDTVYIPTVVGIR-KDGTYT - GLGA- - - L LEKD- -VLVYRDIKRYFGMNKFNAEVYKKKLKPKFEV-

Domains

LRI - - KLNN - - GEISIGSV-GNANAPLMRVVDLVFLFVKGMLLETEEAVGRAVTGVVCT-VPAEYNSFKRESFLGVALEGL-GKPLRALYNEPTSSANALYG - - USLR2 LVKIGSGLNETVSIGNFGGTVKSEAHLPGLIA-LFIKAVISCAEGAFACTCTG-VICSVPANXDSVORNFTDQCVS-LSGYQCVYMINEEPSARAT-SACNS USLR3 --KIDSG--GALLIGGL-GSGPDTLLRVVDVICLFLRALILECERYTSTTVTAAVVT-VPADYNSFKRSFVVEALKGL-GIPVRGVWNEPTAAALYS - - LR4 LVK--.--DWSVSIGPVSGEKGK-TRSVIALACMFVSALAKLAVS ITGEAVTLSV-CSVPAEYSSYMRNF IFQGCNLAK- IQVQAVVNEPIAAGE-SA- - -

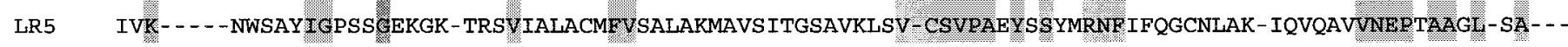

$\mathrm{D}$

LR1 VRGGSLRETY AVF-DFGGGTLDISFISRFNIVVSVLFSKGDNFLGGRDIDRAIVQFLRKE- KRIKGDIDAGILSVMIADLKEKICTNG--GVQQTQV- - USLR2 IGKKSAN - - -LAV-YDFGGGTFDVS I ISYRNNTFVVRASGGDLNLGGRDVDRAFLTHL- - - --FSLT -SLEEDLTLDISNLKESLSKTDAEIVYTLRGVVG USLR3 LAKSRVEDLLLAVF-DFGGGIFDVSFVKKKGNILCVIFSVGDNFLGGRDIDRAIVEVIKQ--KIKGKASDAKLGIF-VSSMKEDLSNNN-AITQHLIPV-LR4 FVAVDKESIEYMVVYDFGGGTELR5 FVTVDKNSIEYMYVYDFGGGTEDASLMAVGSSYVCVVDSLGDNYIGGRDVDNALIDVVVN--

LRI RTSNGLETLSM ---SVDELNAVSEPFIDRAIKIFAEGAEELK-RCPIVCYLTTGGSVALPLVRPKLESLPYVSSVAYDSOTFRLSVAIGAKIYGDIUTGOS - USLR2 RKEDVRV-NKNILTSVMLPYVNRTLKILESTLKSYAKSMNESARVKCDLVLIGGSSYLPGLADVLTKHQSVDRILRVSDP-RAAVAVGCALYSSCLSGSGGUSLR3 --EGG-VEVVD-LTSDELDAIVAPF-SARAVEVFKTGLDNFY - PDPVIAVMTGGSSALVKVRSDVANLPQI SKVVFDSTDFRCSVACGAKVYCDTLAGNSGLR5 VKTLRF-DNQQFRGLCEPFVERARAIIEKLLKRNG- - - - - - VTSCVAVLIGGSSVLPGVRNSVAGLKEISRYIFDKETYRVAVAIGAAIYAQTFTGVSRY

Domains G

LR1 DLRLIDTISQTLSDEL-SGFTALVIFPKGHPIP-SVYETNFQISGSTMEYGIV- - - EGESNRTWLNEIAFKGTD-YRPS - - . - . - . - NE- RRNAGQE USLR2 -LLLIDCAAHTVAIADRSCHQI ICA-PAGAPIPFSGSMPLYLARVNKNSQREVAVFEGEYVKCPKNRKICGANI - -RFFDIGVTEDSYAPVTFYMDFS IS

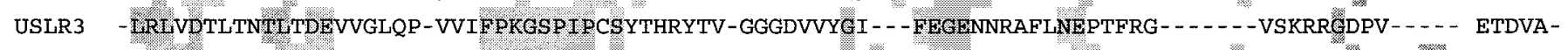
LR5 --RLIECVSNSLSDERQPLQAITVOEPKGHPIP-STVAVNFKMP-TY-NTGVVL-HEGESSFI- -NENARTYSAPLRTSQFPG-GRTYVNEFKILEDGRL

Domains

LR1 RWTKGFHVL

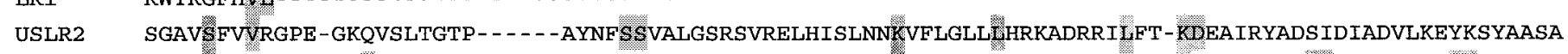

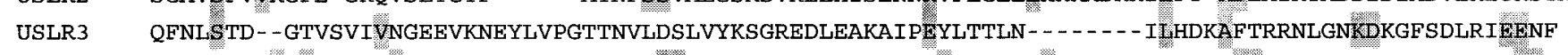
LR5

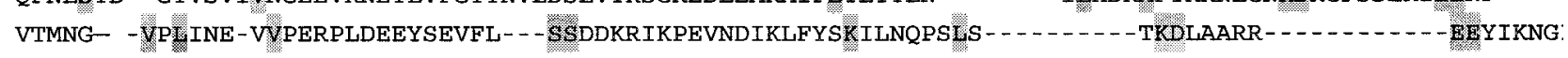

USLR2

LPVPEEDVELLL-GKSVQKVLRGSRLEEIPL

USLR3

LR5

$$
\text { - IVCh }
$$

Fig. 2. Alignment of the heat shock protein 70 (HSP 70) homologue of Grapevine leafroll-associated virus-1 (GLRaV-1) (USLR1), GLRaV-2 (USLR2), GLRaV-3 (USLR3), GLRaV-4 (LR4), and GLRaV-5 (LR5). The conserved motifs (A to H) of cellular HSP are overlined. 
detected with the BLAST 2 sequence program (34). The percentage of similarity among GLRaV-5 capsid protein and diverged duplicate capsid protein with other closterovirus homologues is shown in Table 3.

The phylogenetic analyses showed that GLRaV-5 capsid protein clustered with the capsid protein of the Australian strain of GLRaV-1, as well as the GLRaV-3 capsid protein and duplicate capsid protein (data not shown). As expected, GLRaV-2 capsid protein and duplicate capsid protein clustered with CTV and BYSV capsid proteins. The aa sequences of GLRaV-5 duplicate capsid protein and a GLRaV-4 gene of unknown function (10) clustered in a completely separate lineage branch. This data suggests that the unknown gene sequences reported by Fazeli et al. (10) might be the GLRaV-4 diverged capsid protein.

The sequence analyses of the GLRaV-5 partial genome indicates that the capsid protein is located upstream from the diverged duplicate capsid protein coding sequence, similar to that reported for GLRaV-1 (11) and GLRaV-3 (21). This is in contrast to BYV, CTV, and GLRaV-2, where the duplicate coat protein coding sequence is located upstream from the capsid protein coding sequence.

In vitro expression of the GLRaV-5 coat protein and production of antiserum. The recombinant GLRaV-5 capsid protein (rec GLRaV-5 CP) was analyzed in immunoblots with a MAb against GLRaV-5 coat protein. The results indicate that the recombinant protein reacted with the GLRaV-5 antibodies specifically (Fig. 4A). The recombinant protein did not react with PAbs against GLRaV-1, GLRaV-2, and GLRaV-4, or with MAbs against GLRaV-8 (data not shown).

The affinity-purified rec GLRaV-5 CP preparation was used to immunize rabbits for the production of antiserum. This polyclonal antiserum (rec GLRaV-5 CP PAb) specifically reacted with extracts from plants infected with GLRaV-5 (Fig. 4B). The reactivity of commercially available GLRaV-5 PAbs (Sanofi Diagnostics Pasteur) and GLRaV-5 MAbs (14) with virus-infected tissue were compared with that of rec GLRaV-5 CP PAb. The immunoblot analyses showed that the 36-kDa-specific GLRaV-5 polypeptide is almost undetectable in the extracts probed with commercially available GLRaV-5 PAbs (Fig. 4C) and GLRaV-5 MAbs (Fig. 4D). In contrast, rec GLRaV-5 CP PAb revealed a strong reactivity to GLRaV-5-specific antigens (Fig. 4B). Rec GLRaV-5 CP PAb had stronger comparative reactivity even when used four times more diluted (Fig. 4B). All lanes in the immunoblots shown in Figure 4 represent polyacrylamide gels loaded with the same amount of protein from the same preparations of each virus source (e.g., LR 100 or LR 102).

Specific detection of GLRaV-1 and GLRaV-5 nucleic acids. Four sets of PCR primers were designed for the detection of GLRaV-1, GLRaV-5, or both viruses. The LR5-1F and LR5-1R primers (nt 3411 to 3431 and 4081 to 4099, respectively) were designed for the amplification of a specific fragment from the GLRaV-5 coat protein (ORF C). This primer set yielded a DNA fragment of approximately $690 \mathrm{nt}$ in plant material infected with GLRaV-5 (Fig. 5, lanes 1 and 5), but no PCR products from ex-

TABLE 3. Percentage of amino acid similarity between heat shock protein 70 (HSP 70), capsid protein (CP), and diverged duplicate capsid protein (dCP) encoded by Grapevine leafroll-associated virus-5 (GLRaV-5) and homologues encoded by other closteroviruses ${ }^{\mathrm{a}}$

\begin{tabular}{lccc}
\hline Virus & HSP 70 & CP & dCP \\
\hline GLRaV-1 (AU) & 33 & 32 & NS \\
GLRaV-1 (U.S.) & 35 & NA & NA \\
GLRaV-2 & 29 & 33 & NS \\
GLRaV-3 & 32 & 37 & NS \\
GLRaV-4 & 90 & NA & 70 \\
Little cherry virus & 26 & NS & NS \\
Beet yellow stunt virus & 30 & 21 & NS \\
Citrus tristeza virus & 27 & NS & NS
\end{tabular}

a Amino acid sequence similarity was obtained from pairwise comparisons using the BLAST 2 sequences program (34). GLRaV-1 from Austria and the United States depostited in Genbank as Accession Nos. AF195822 and AF233935, respectively. NA = sequence not available; NS = no significant identity. The partial sequences, 216 and 126 a from the GLRaV-4 HSP 70 (AF039553) and a gene of unknown function (AF030168), respectively were available for this study.

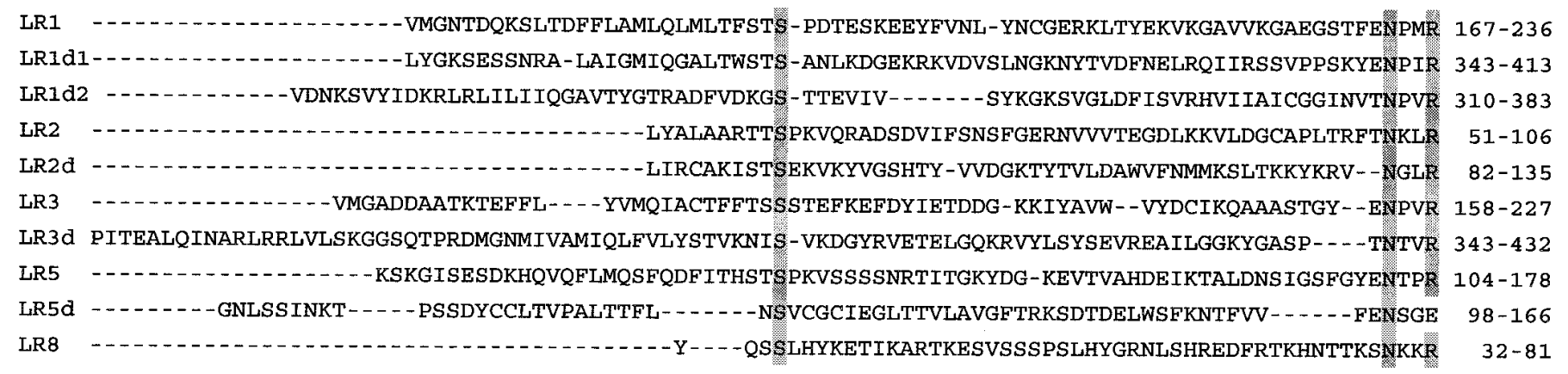

LR1 -QYARLFSATAVHLILNGKLKPNEKVAMQHEVPKRFLPYTFDFC--RPSYSQFSNDAIRAWQLAAESAFG-R KSNVTSSVLRNTSE-- - - -L-KV IRId1-QYMRWFSTTTISLIKSGVVVPNYHV-ARHGVTSQF IPYGFWYCILLPS- -YNRRDDKVAAALARAQAVALANK -RAGKTLYNFSELG- - - - KS LRId2 -QYMRWWSTVTIQLIKLGIVKPNPIVAARRELTNNNTWLSFDYILLDAR LR2 TFGRTFTEAYVDFCIAYKHKLPQLNAAAELGI PAEDSYLAADFLGTCPKLSELQQSRK-MFASMYAL-KTEGGVVNTPVSNLRQLGRR-- -EVM LR2d AFCCACEDLYLTVAPIM-SERFKTKAVGMKGLPVGKEYIGADFLSGTSKLMSDHDRAVSIVAAKNAVDRSAFTGGERKIVSLYDLGRY LR3 -QYLAYFTPTF ITATLNGKLVMNEKVMAQHGVPPKFFPYTIDCVRPTYDLFNNDAILAWNLARQQAF - RNKTVTADNTLHNVFQ- - - - - - LLQKK LR3d -SFMRYFAHTTITLLIEKKIQPACTALAKHGVPKRFTPYCFEFALLDNRYYPADVLKANAMACAIAI - - KSANLRRKGSETYN - - - - - ILESI LR5 -QFGRAFTAAIVQGISSGKLEVNTKICASHEVPPNYYPYSP LR5d ISTFYGDSMDTSN--SA-LLEVLDSFGSTSGKT- - - - VFEKVVSLLSI LR8 VCAAQI---KQR

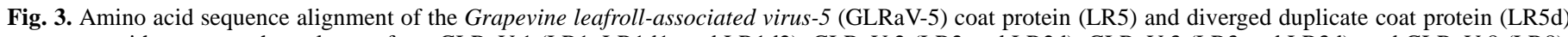

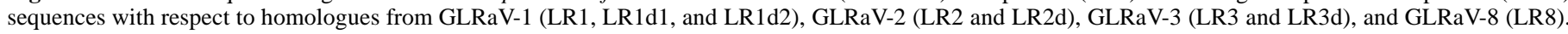
The conserved SNRGD sequence is highlighted in gray. 
tracts of plants uninfected (lane 9) or singly infected with GLRaV1 (Fig. 5, lane 10), GLRaV-2 and -3 (data not shown), GLRaV-4 (Fig. 5, lane 11), or GLRaV-8 (data not shown). The LR5-5F and LR5-5R primers were designed based on the sequences upstream from the HSP 70 gene of a cDNA clone produced from the LR 102 virus source (J. Monis, unpublished data). This primer set yielded a PCR product of approximately 600 nt from GLRaV-1, -5 , and -8 infected material, but no PCR products from extracts of plants uninfected or infected with GLRaV-2, -3, -4, or -6 (Fig. 5, lanes 2 and 6) (data not shown). The GSP1 and GSP9 primers (nt 356 to 379 and 557 to 579 , respectively) were designed based on the GLRaV-5 HSP 70 homologue protein gene (ORF A) sequence and yielded a product of $200 \mathrm{nt}$ in grapevine material infected with both GLRaV-1 and -5 (Fig. 5, lanes 3 and 7) (data not shown). Further sequence analyses revealed that the GSP9 primer had a 2-bp mismatch at $5^{\prime}$ end. The GSP3 and GSP4 primers were designed based on the GLRaV-1 HSP 70 homologue protein gene sequence and yielded a product of $150 \mathrm{nt}$ in GLRaV1 infected material (Fig. 5, lane 8), but yielded no PCR products from extracts of plants uninfected (data not shown) or infected with GLRaV-5 (Fig. 5, lane 4), -2, -3, or -4 (data not shown).

\section{DISCUSSION}

The work reported here has extended our knowledge on the molecular characterization of an additional grapevine-infecting closterovirus, GLRaV-5. The in vitro expression of ORF C from this virus for the production of antiserum against the expressed protein has yielded information demonstrating that this protein is the bonafide capsid protein. The calculated molecular mass of $29 \mathrm{kDa}$ deduced from the aa sequence of the capsid protein is smaller than the $36 \mathrm{kDa}$ estimated by sodium dodecyl sulfatepolyacrylamide gel electrophoresis (SDS-PAGE). It is not known if this discrepancy is due to a posttranslational modification or an artifact of SDS-PAGE analyses. Similar discrepancies have been reported for the cloned ORF coding for the GLRaV-3 capsid protein (22).

An important aspect of the characterization of GLRaV-5 is the development of new tools for the detection of this virus. Although a MAb against the GLRaV-5 capsid protein has been produced (14) and a PAb is commercially available, these reagents have relatively low titers (Fig. 4C and D). The polyclonal antiserum against the recombinant GLRaV-5 capsid protein reported in this study had a stronger reactivity to GLRaV-5 in immunoblots compared with other serological reagents available (Fig. 4). This new antiserum will allow the development of enzyme-linked immunosorbent assays for the quick and reliable detection of GLRaV-5. Furthermore, the availability of cDNA clones and specific PCR primer sets provide the grapevine industry with a new tool for the sensitive detection of GLRaV-1 and -5 (Fig. 5) (data not shown).

The sequence analyses of GLRaV-5 specific clones has shown sequence identity to other members of the closterovirus group. Our sequence comparisons revealed that GLRaV-5 has a closer identity with GLRaV-1, -3 , and -4 than with GLRaV-2, BYSV, and CTV. Interestingly, a recent phylogenetic analysis shows the 216 N-terminal fragment of GLRaV-1, -3, -4, and -5 HSP 70 homologue genes cluster in the same lineage of mealybug-transmitted closteroviruses (16).

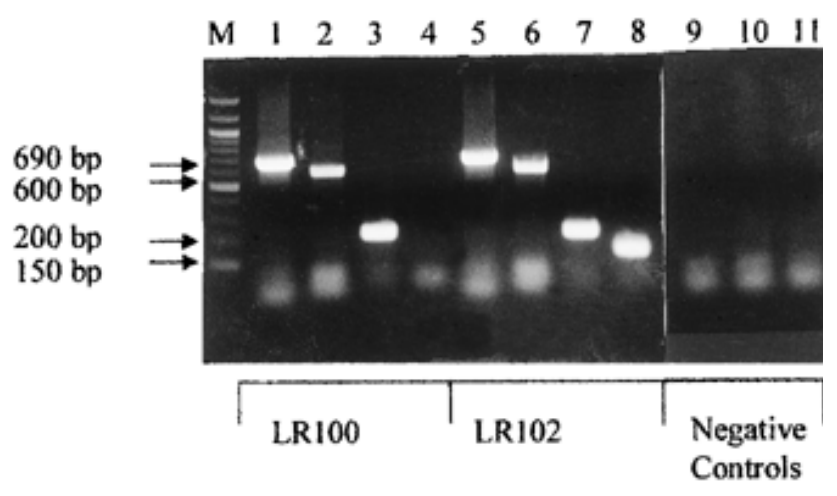

Fig. 5. Ethidium bromide-stained agarose gel showing the detection of Grapevine leafroll-associated virus-1 (GLRaV-1) and GLRaV-5 in diseased grapevines by the polymerase chain reaction (PCR). Primer sets used: LR51F/1R (lanes 1 and 5), LR52F/2R (lanes 2 and 6), GSP 1/9 (lanes 3 and 7), and GSP $3 / 4$ (lanes 4 and 8). RNA was extracted from virus preparations or tissue of the LR 100 (LR100) and LR 102 (LR102) virus sources. The negative controls were conducted with LR5 1F and LR5 1R primers with RNA isolated from uninfected grapevine tissue (lane 9), GLRaV-1 infected grapevine tissue (lane 10), and GLRaV-4 infected grapevine tissue (lane 11). The approximate sizes of the PCR products are shown on the left.

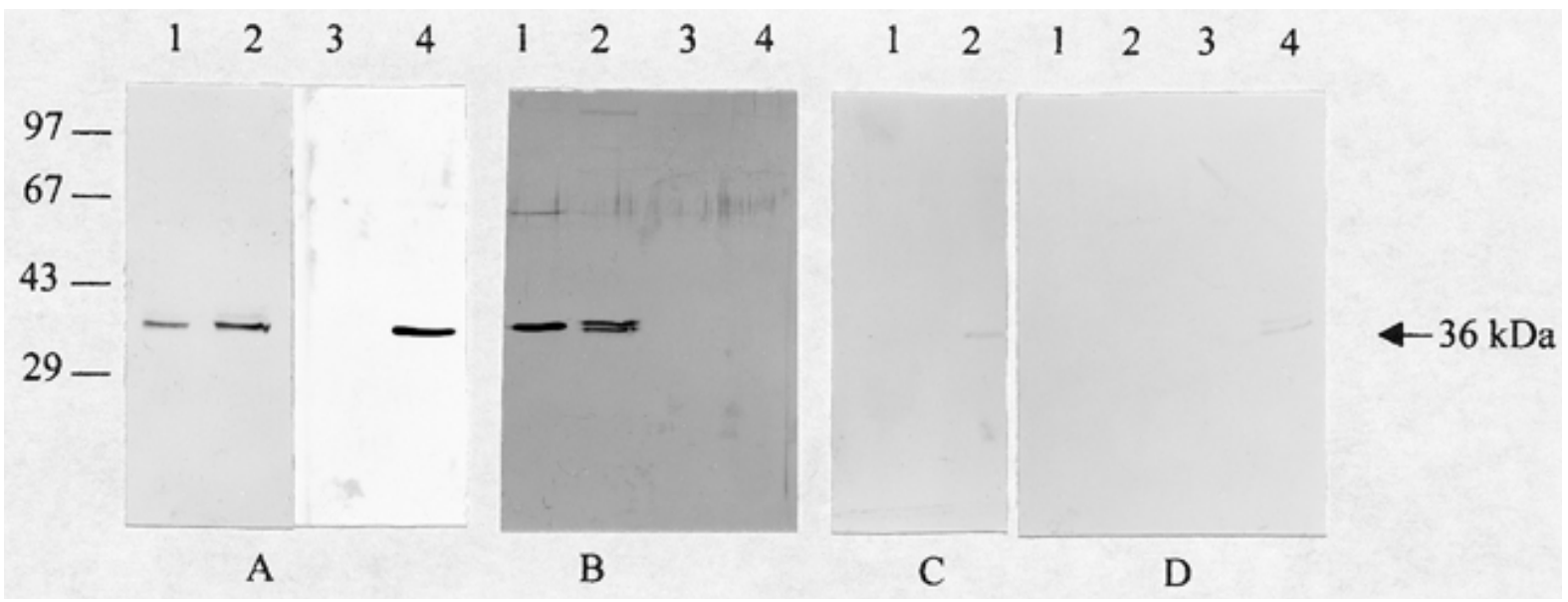

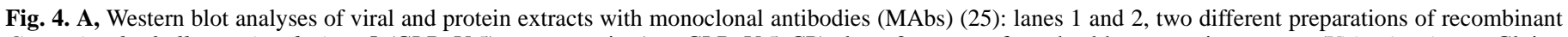

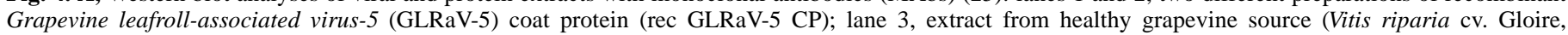

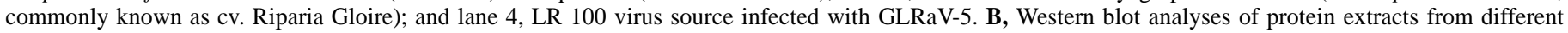

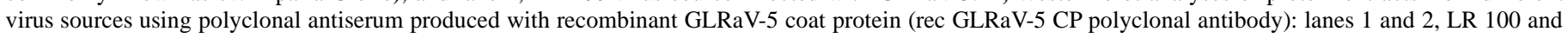

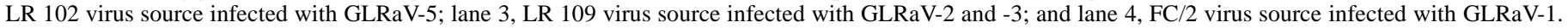

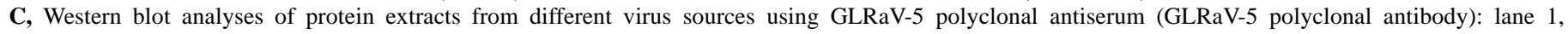

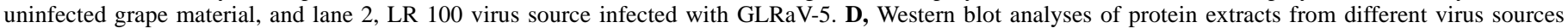

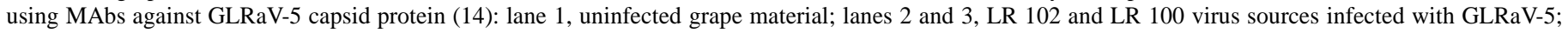

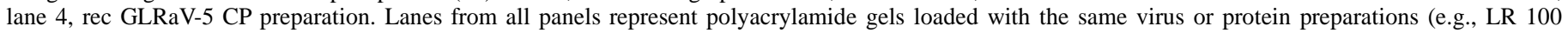
extracts: A, lane 4; B, lane 1; C, lane 2; and D, lane 3) and equivalent protein concentration. 
When comparing the HSP 70 homologue and capsid protein aa sequences, the least similarity was found with $\mathrm{LChV}$, a closterovirus reported to have a large molecular weight capsid protein and to be mealybug-transmitted (15). Different research groups $(6,30$, 31,33) have demonstrated mealybug transmission of GLRaV-1 and -3 , but no information is presently available on the insect transmissibility of GLRaV-5.

A high degree of similarity between the sequences of a GLRaV-4 protein with unknown function (10) and the GLRaV-5 diverged duplicate capsid protein was found. Also, a close relationship of the partial nt and deduced aa sequence of GLRaV-4 and GLRaV-5 HSP 70 homologue was detected. In a separate report, we determined the presence of common epitopes in GLRaV-4, -5 , and -8 (25). Although the available information suggests that GLRaV-4 and -5 are closely related, more studies will be needed to accurately determine the relationship of these viruses.

Our phylogenetic studies showed that GLRaV-5 HSP 70, capsid protein, and duplicate capsid protein genes clustered in the same lineage with the respective GLRaV-1 and GLRaV-3 homologous genes (data not shown). A discrepancy was found when the partial HSP 70 aa sequences of GLRaV-4 and -5 were compared with the complete HSP 70 aa sequences of GLRaV-1, -2, -3, and -5. The unexpected results and unreliable phylogenetic trees could be caused by errors in the initial aa sequence alignment and have been recently discussed by Karasev (16).

In this study we have shown that the order of GLRaV-5 capsid protein and diverged duplicate capsid protein is similar to that reported for GLRaV-1 (11) and GLRaV-3 (21). Based on the information available on the genome organization of GLRaV-3, Karasev (16) proposed a modification of the current Closteroviridae classification, adding a new genus (Vinivirus) comprising the mealybug-transmitted closteroviruses with GLRaV-3 as the type representative. The molecular information available to date suggests the inclusion of GLRaV-5 in the proposed genus. Additional molecular and epidemiological research will further our understanding on the insect transmission, genome organization, and sequence relatedness of the members of this complex group of GLRaVs of the genus Closterovirus.

\section{ACKNOWLEDGMENTS}

This research was supported in part by the U.S. Department of Agriculture SBIR grants 94-33610-0078 and 95-33610-1958 awarded to J. Monis. We thank F. Negru for technical assistance, C. Pico for help on figure preparation, A. Minafra and G. P. Martelli for assistance with the phylogenetic analyses, and V. Dolja and A. Karasev for helpful discussions and critical review of the manuscript.

\section{LITERATURE CITED}

1. Abou-Ghanem, N., Sabanadzovic, S., Minafra, A., Saldarelli, P., Castellano, M. A., and Martelli, G. P. 1997. Physico-chemical and molecular characterization of grapevine leafroll-associated virus-2. Pages 15-16 in: 12th International Committee on the Taxonomy of Viruses, Lisbon, Portugal.

2. Agranovsky, A. A., Koonin, E. V., Bokyo, V. P., Maiss, E., Frotschi, R., Lunina, N. A., and Atabekov, J. G. 1994. Beet yellows closterovirus: Complete genome structure and identification of papain-like thiol protease. Virology 198:311-324.

3. Altschul, S. F., Madden, T. L., Schäffer, A. A., Zhang, Z., Miller, W., and Lipman, D. J. 1997. Gapped BLAST and PSI-BLAST: A new generation of protein database search programs. Nucleic Acids Res. 25:3389-3402.

4. Alzhanova, D. V., Hagiwara, Y., Peremyslow, V. V., and Dolja, V. V. 2000. Genetic Analyses of the cell-to-cell movement of beet yellows closterovirus. Virology 268:192-200.

5. Boscia, D., Greif, C., Gugerli, P., Martelli, G. P., Walter, B., and Gonsalves, D. 1995. Nomenclature of grapevine leafroll-associated putative Closteroviruses. Vitis 34:171-175.

6. Cabaleiro, C., and Segura, A. 1997. Some characteristics of the transmission of grapevine leafroll associated virus 3 by Planococcus citri Risso. Eur. J. Plant Pathol. 103:373-378.

7. Choueiri, E., Boscia, D., Digiaro, M., Castellano, M. A., and Martelli, G.
P. 1996. Some properties of a hitherto undescribed filamentous virus of the grapevine. Vitis 35:91-93.

8. De Paulo, J. J., and Powell, C. A. 1995. Extraction of double-stranded RNA from plant tissues without use of organic solvents. Plant Dis. 79:246-248.

9. Dolja, V. V., Karasev, A. V., and Koonin, E. V. 1994. Molecular biology and evolution of Closteroviruses: Sophisticated build-up of large RNA genomes. Annu. Rev. Phytopathol. 32:261-285.

10. Fazeli, C. F., Habili, N., and Rezaian, M. A. 1998. Efficient cloning of cDNA from grapevine leafroll-associated virus-4 and demonstration of probe specificity by the viral antibody. J. Virol. Methods 70:201-211.

11. Fazeli, C. F., and Rezaian, M. A. 2000. Nucleotide sequence and organization of ten open reading frames of the grapevine leafroll-associated virus-1 genome and identification of three subgenomic RNAs. J. Gen. Virol. 81:605-615

12. Goheen, A. 1988. Leafroll disease. Page 52 in: Compendium of Grape Diseases. R. C. Pearson and A. C. Goheen, eds. The American Phytopathological Society, St. Paul, MN.

13. Golino, D. A. 1992. The Davis grapevine virus collection. Am. J. Enol. Vitic. 43:200-205

14. Gugerli, P., and Ramel, M. E. 1993. Grapevine leafroll associated virus 2 analyzed by monoclonal antibodies. 11th International Council for the Study of Viruses and Virus Diseases of the Grapevine, Montreux, Switzerland.

15. Jelkmann, W., Fletchner, B., and Agranovsky, A. A. 1997. Complete genome structure and phylogenetic analyses of little cherry virus, a mealybug-transmissible closterovirus. J. Gen. Virol. 78:2067-2071.

16. Karasev, A. V. 2000. Genetic diversity and evolution of closteroviruses. Annu. Rev. Phytopathol. 38:293-324

17. Karasev, A. V., Bokyo, V. P., Gowda, S., Nikolaeva, O. V., Hilf, M. E., Koonin, E. V., Niblett, C. L., Cline, K., Gumpf, D. J., Lee, R. F., Garnsey, S. M., Lewandowski, D. J., and Dawson, W. O. 1995. Complete sequence of the citrus tristeza virus RNA genome. Virology 208:511-520.

18. Karasev, A. V., Nikolaeva, O. V., Koonin, E. V., Gumpf, D. J., and Garnsey, S. M. 1994. Screening the closterovirus genome by degenerate primer mediated polymerase chain reaction. J. Gen. Virol. 75: $1415-1422$.

19. Karasev, A. V., Nikolaeva, O. V., Mushegian, A. R., Lee, R. F., and Dawson, W. O. 1996. Organization of the $3^{\prime}$-terminal half of beet yellow stunt virus genome and implications for the evolution of Closteroviruses. Virology 221:199-207.

20. Klaassen, V. A., Boeshore, M., Dolja, V. V., and Falk, B. W. 1994. Partial characterization of the lettuce infectious virus genomic RNAs, identification of the coat protein gene and comparison of its amino acid sequence with those of other filamentous RNA plant viruses. J. Gen. Virol. 75:1525-1533.

21. Ling, K. S., Krastanova, T., Xue, B., Zhu, H. Y., Meng, B., and Gonsalves, D. 2000. Complete genome sequence of grapevine leafroll virus-3 and development of transgenic plants expressing its genes. Page 52 in: 13th International Council for the Study of Virus Diseases of the Grapevine, Adelaide, Australia.

22. Ling, K. S., Zhu, H. Y., Drong, R. F., Slightom, J. L., McFerson, J. R., and Gonsalves, D. 1997. The coat protein of grapevine leafroll associated closterovirus-3, nucleotide sequencing and expression in transgenic plants. Arch. Virol. 142:1101-1116.

23. MacKenzie, D. J., McLean, M. A., Mujerji, S., and Green, M. 1997. Improved RNA extraction of woody plants for the detection of viral pathogens by reverse transcription polymerase chain reaction. Plant Dis. 81:222-226.

24. Martelli, G. P. 2000. Grapevine virology highlights 1997-99. Pages 1-5 in: 13th International Council for the Study of Virus Diseases of the Grapevine, Adelaide, Australia.

25. Monis, J. 2000. The development of monoclonal antibodies reactive to a new grapevine leafroll-associated Closterovirus. Plant Dis. 84:858-862.

26. Monis, J., and Bestwick, R. 1996. Detection and localization of grapevine leafroll associated Closteroviruses in greenhouse and tissue culture grown grapevines. Am. J. Enol. Vitic 47:199-205.

27. Monis, J., and Bestwick, R. 1997. Serological characterization of grapevine-associated Closteroviruses in grapevine cultivars. Plant Dis. $81: 802-808$

28. Monis, J., and de Zoeten, G. A. 1990. Molecular cloning and physical mapping of potato virus S complementary DNA. Phytopathology 80:446-450

29. Peremyslov, V. V., Hagiwara, Y., and Dolja, V. V. 1999. HSP70 homologue functions in cell-to-cell movement of a plant virus. Proc. Natl. Acad. Sci. 96:14771-14776.

30. Petersen, C. L., and Charles, J. G. 1997. Transmission of grapevine leafroll-associated closteroviruses by Pseudococcus longispinus and $P$. calceolariae. Plant Pathol. 46:509-515.

31. Rociglione, B., and Gugerli, P. 1989. Transmission of grapevine leafroll 
disease and an associated closterovirus to healthy grapevine by the mealybug Planococcus ficus. (Abstr.) Phytoparasitica 17:63.

32. Routh, G., Zhang, Y.-P., Saldarelli, P., and Rowhani, A. 1998. Use of degenerate primers for partial sequencing and RT-PCR-based assays of grapevine leafroll-associated viruses 4 and 5. Phytopathology 88: 1238-1243.

33. Sforza, R., Komar, V., and Grief, C. 2000. New scale vectors of grapevine Closteroviruses. Page 14 in: International Council for the Study of Virus Diseases of the Grapevine, 13th, Adelaide, Australia.

34. Tatusova, T. A., and Madden, T. L. 1999. BLAST 2 sequences, a new tool for comparing protein and nucleotide sequences. FEMS Microbiol.
Lett. 174:247-250.

35. Tian, T., Klaassen, V. A., Soong, J., Wisler, G., Duffus, J. E., and Falk, B. W. 1996. Generation of cDNAs specific to lettuce infectious yellows closterovirus and other whitefly-transmitted viruses by RT-PCR and degenerate oligonucleotide primers corresponding to the closterovirus gene encoding the heat shock protein 70 homologue. Phytopathology 86:1167-1173

36. Zhu, H.-Y., Ling, K. S., Goszczynski, D. E., McFerson, J. R., and Gonsalves, D. 1998. Nucleotide sequence and genome organization of grapevine leafroll-associated virus-2 are similar to beet yellows virus, the closterovirus type member. J. Gen. Virol. 79:1289-1298. 